\title{
Application of Nanoparticle Iron Oxide in Cigarette for Simultaneous CO and NO Removal in the Mainstream Smoke*
}

\author{
by \\ Ping Li, Firooz Rasouli, and Mohammad R. Hajaligol \\ Research Center, Philip Morris USA Inc., Richmond, Virginia 23234, USA.
}

\section{SUMMARY}

Based on the unique temperature and oxygen profiles in a burning cigarette, a novel approach is proposed in this paper to use a single oxidant/catalyst in the cigarette filler for simultaneous removal of carbon monoxide $(\mathrm{CO})$ and nitric oxide (NO) in mainstream smoke. A nanoparticle iron oxide is identified as a very active material for this application due to its multiple functions as a $\mathrm{CO}$ catalyst, as a $\mathrm{CO}$ oxidant, and in its reduced forms as a NO catalyst. The multiple functions of the nanoparticle iron oxide are characterized in a flow tube reactor and the working mechanisms of these multiple functions for $\mathrm{CO}$ and NO removal in a burning cigarette are explained. The effect of smoke condensate on the catalyst are examined and discussed. The advantage of in situ generation of the catalyst during the cigarette burning process is illustrated. The test results of nanoparticle iron oxide for $\mathrm{CO}$ and $\mathrm{NO}$ removal in cigarettes are presented. [Beitr. Tabakforsch. Int. 21 (2004) 1-8]

\section{ZUSAMMENFASSUNG}

Auf der Basis der in einer brennenden Zigarette herrschenden Temperatur- und Sauerstoffprofile wird eine neue Vorgehensweise vorgeschlagen, bei der mit einem einzigen Oxidans/Katalysator im Füllmaterial für Zigaretten gleichzeitig sowohl Kohlenmonoxid (CO) als auch Stickoxid (NO) aus dem Hauptstromrauch von Zigaretten entfernt werden. Es wurde herausgefunden, dass ein Nanopartikel-Eisenoxid aufgrund seiner verschiedenen Funktionen als CO-Katalysator, CO-Oxidans und in reduzierten Formen vorliegend als NO-Katalysator für diesen Zweck sehr wirkungsvoll eingesetzt werden kann. Die verschiedenen Funktionen des Nanopartikel-Eisenoxids wurden in einem Durchflussreaktor bestimmt und die Mechanismen dieser mehrfachen Funktionen zum Entfernen von $\mathrm{CO}$ und $\mathrm{NO}$ aus einer brennenden Zigarette erklärt. Die Wirkung von Rauchkondensat auf den
Katalysator wird untersucht und diskutiert. Der Vorteil einer in situ Generierung des Katalysators während des Brennvorgangs der Zigarette wird beschrieben. Die Versuchsergebnisse der Eliminierung von $\mathrm{CO}$ und $\mathrm{NO}$ aus Zigarettenrauch durch Nanopartikel-Eisenoxid werden präsentiert. [Beitr. Tabakforsch. Int. 21 (2004) 1-8]

\section{RESUME}

Basé sur des profils uniques de température et d'oxygène dans une cigarette en combustion, une nouvelle approche, utilisant un seul oxydant/catalyseur dans la charge des cigarettes pour l'élimination simultanée du monoxyde de carbone $(\mathrm{CO})$ et du monoxyde d'azote (NO) de la fumée principale de cigarettes, est proposée. Une nanoparticule d'oxyde de fer a été identifiée comme étant un matériau très actif dans ce contexte, en raison de ses fonctions multiples comme catalyseur de $\mathrm{CO}$, oxydant de $\mathrm{CO}$ et, sous forme réduite, comme catalyseur de NO. Les fonctions multiples de cette nanoparticule d'oxyde de fer ont été caractérisées dans un «flow tube reactor » (tube à flux) et les mécanismes de ces fonctions multiples d'élimination de $\mathrm{CO}$ et $\mathrm{NO}$ d'une cigarette en combustion sont expliqués. L'effet du condensat de la fumée sur le catalyseur est examiné et discuté. L'avantage d'une génération in situ du catalyseur au cours de la combustion de la cigarette est élucidé. Les résultats des essais d'élimination du $\mathrm{CO}$ et du NO des cigarettes par des nanoparticules d'oxyde de sont présentés. [Beitr. Tabakforsch. Int. 21 (2004) 1-8]

\section{INTRODUCTION}

Carbon monoxide (CO) and nitric oxide (NO) are products of tobacco pyrolysis and combustion. The sources of $\mathrm{CO}$ from a burning cigarette, according to the pioneering studies of R.R. BAKER $(1,2,3)$, are roughly around $30 \%$ 
Quartz Wool Dusted with Catalyst

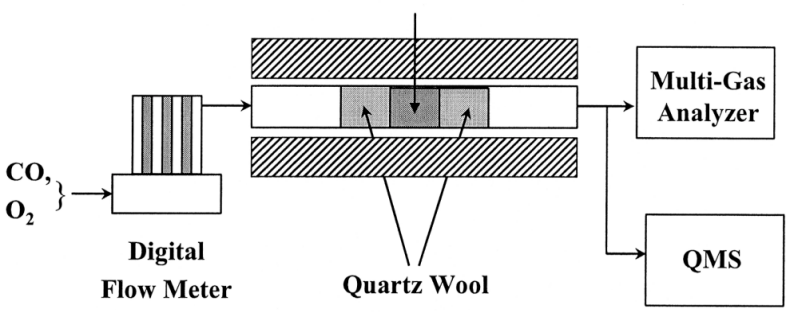

Figure 1. The schematic of the flow tube reactor setup

from thermal decomposition, $36 \%$ from combustion, and at least $23 \%$ from reduction of carbon dioxide $\left(\mathrm{CO}_{2}\right)$ by carbonized tobacco. Comparatively, the sources of $\mathrm{NO}$ and its formation are not as clear. It probably comes from the combustion and decomposition of the nitrogen containing compounds. A recent study by IM et al. (4) suggests new pathways for NO formation.

Over the years, many empirical approaches have been proposed and tried to remove $\mathrm{CO}$ and $\mathrm{NO}$, especially $\mathrm{CO}$, in the mainstream smoke. For $\mathrm{CO}$, these approaches include dilution, filtration, direct oxidation and catalytic oxidation. The obvious problem for dilution is the indiscriminate removal of other smoke constituents. For filtration, there is still no adsorbent available that can selectively adsorb a substantial amount of $\mathrm{CO}$ at ambient temperature. The direct oxidation and catalytic oxidation approaches have also received a significant amount of research work However, due to the high level of complexity in a burning cigarette and the coating and deactivating of the catalyst by the smoke condensate downstream of the burning zone in the cigarette rod, no $\mathrm{CO}$ catalyst has reached commercial application in cigarettes yet.

In this paper, a novel working mechanism is proposed to utilize the unique axial temperature and oxygen profiles in a burning cigarette and use a single oxidant/catalyst distributed in the cigarette filler for simultaneous removal of both $\mathrm{CO}$ and $\mathrm{NO}$ in the mainstream smoke. A nanoparticle iron oxide called NANOCAT ${ }^{\circledR}$ Superfine iron oxide (referred to as NANOCAT® $\mathrm{Fe}_{2} \mathrm{O}_{3}$ hereafter), manufactured by MACH I, Inc., King of Prussia, PA, is identified as a promising material for this application. This nanoparticle, with an average particle size of $3 \mathrm{~nm}$, consists of the crystalline phase of $\mathrm{FeOOH}, \gamma-\mathrm{Fe}_{2} \mathrm{O}_{3}$, and some amorphous phases. The multiple functions of NANOCAT® $\mathrm{Fe}_{2} \mathrm{O}_{3}$ as a $\mathrm{CO}$ catalyst, as a $\mathrm{CO}$ oxidant and in its reduced forms as a NO catalyst are characterized by the flow tube method. The influence of the smoke condensate on the performance of the catalyst is evaluated and the advantage of generating catalyst in situ during the burning process is illustrated. The test results of NANOCAT ${ }^{\circledR} \mathrm{Fe}_{2} \mathrm{O}_{3}$ for $\mathrm{CO}$ and $\mathrm{NO}$ removal in cigarettes are also presented.

\section{EXPERIMENTAL SETUP}

Two types of experiments were carried out. A flow tube reactor system was used to characterize the catalytic and oxidative properties of NANOCAT ${ }^{\circledR} \mathrm{Fe}_{2} \mathrm{O}_{3}$. The effectiveness of NANOCAT® $\mathrm{Fe}_{2} \mathrm{O}_{3}$ in removing $\mathrm{CO}$ and $\mathrm{NO}$ in the

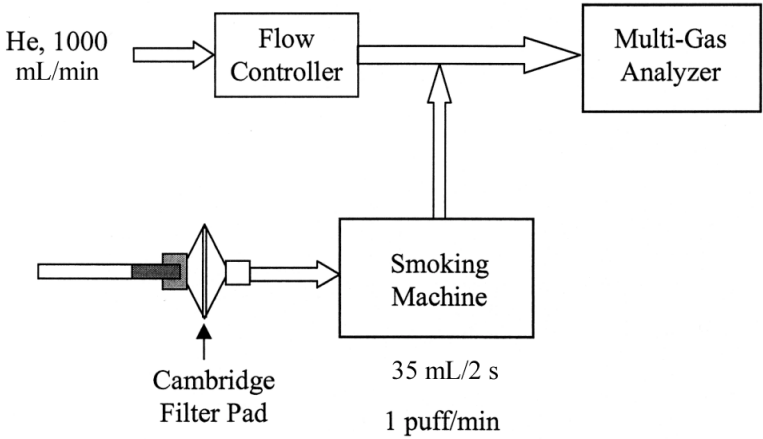

Figure 2. The schematic of the puff-by-puff smoke analyzer

mainstream smoke of a burning cigarette was tested by a puff-by-puff analyzer system. The two experimental setups are described here separately.

Flow tube reactor system

Experiments were carried out by using a quartz flow tube reactor (length $50 \mathrm{~cm}$, i.d. $0.9 \mathrm{~cm}$ ). A schematic diagram is shown in Figure 1. A piece of quartz wool dusted with a known amount of NANOCAT® $\mathrm{Fe}_{2} \mathrm{O}_{3}$ was placed in the middle of the flow tube, sandwiched by the two other pieces of quartz wool. The quartz flow tube was then placed inside a Thermcraft furnace (Thermcraft, Inc., Winston-Salem, NC) controlled by a temperature programmer. The sample temperature was monitored by an Omega K-type thermocouple (OMEGA Engineering, Inc., Stamford, CT) inserted into the dusted quartz wool. Another thermocouple was placed in the middle of the furnace, outside the flow tube, to monitor and record the furnace temperature. The temperature data were recorded by a Labview-based program (National Instruments Corporation, Austin, TX). Since the catalytic oxidation of CO is very exothermic, the catalyst bed's temperature could be significantly higher than the heating furnace's temperature, depending on $\mathrm{CO}$ concentration and the flow rate.

The inlet gases were controlled by a Hastings Instruments digital flow meter, model HFC 202 (Hastings Instruments, Norfolk, England). The gases were mixed before entering the flow tube. The effluent gas was analyzed either by a Rosemount Analytical's NGA2000-MLT multi-gas analyzer (ROSEMOUNT Analytical, Process Analytic Division, Orrville, $\mathrm{OH}$ ) or a Balzer Thermal Star quadrupole mass spectrometer (Pfeiffer Vacuum GmbH, Asslar, Germany) through a sampling capillary. The multi-gas analyzer used three non-dispersive near infrared detectors for the measurements of $\mathrm{CO}, \mathrm{CO}_{2}$ and $\mathrm{NO}$, respectively, and one paramagnetic detector for the measurement of oxygen $\left(\mathrm{O}_{2}\right)$. When the mass spectrometer was used as the monitor, a $15 \%$ contribution from the fragmentation of $\mathrm{CO}_{2}(\mathrm{~m} / \mathrm{e}=44)$ to $\mathrm{CO}(m / e=28)$ had been accounted for.

\section{Puff-by-puff smoking test system}

The control and experimental cigarettes were smoked by a single port, puff-by-puff smoking machine. The outlet of the smoking machine was coupled to a multi-gas analyzer as shown in Figure 2. The smoking machine smoked the cigarettes according to Federal Trade Commission (FTC) 


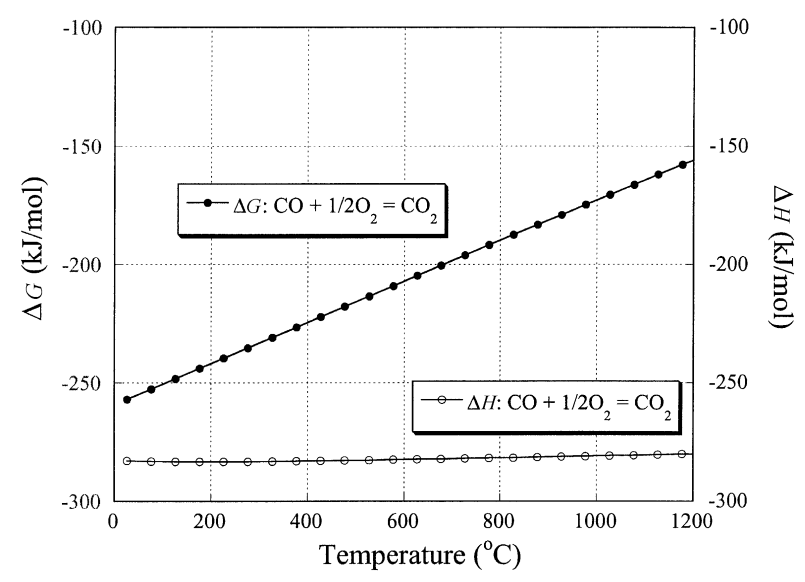

Figure 3. The temperature dependence of $\Delta H$ (enthalpy) and $\Delta G$ (Gibbs free energy) for the $\mathrm{CO}+1 / 2 \mathrm{O}_{2}=\mathrm{CO}_{2}$ reaction

conditions ( $35 \mathrm{~mL} / 2 \mathrm{~s}$, one puff per minute). Each $35 \mathrm{~mL}$ puff of smoke was injected into the $1000 \mathrm{~mL} / \mathrm{min}$ helium stream, which carried the injected smoke to the multi-gas analyzer. The flow rate of the helium stream was controlled by a Hastings digital flow meter. The NGA2000-MLT multigas analyzer can measure the concentrations (by volume percentage) of $\mathrm{CO}$ and $\mathrm{NO}$ in a continuous flow, even with the presence of other organic compounds. The measurement was taken every second to ensure a close monitoring of the concentration changes. The measured concentration data, along with time were logged on a computer for analysis. The integration of the concentration vs. time gives the quantities of $\mathrm{CO}$ and NO production during the puff-by-puff smoking process. According to the ideal gas law, the gas volume per mmol at $25{ }^{\circ} \mathrm{C}$ can be calculated as follows:

$$
\begin{aligned}
\frac{V}{n} & =\frac{R T}{P}=\frac{0.08206\left(\frac{\mathrm{L} \cdot \mathrm{atm}}{\mathrm{K} \cdot \mathrm{mol}}\right) \cdot 298.15(\mathrm{~K})}{1(\mathrm{~atm})} \\
& =24.45\left(\frac{\mathrm{mL}}{\mathrm{mmol}}\right)
\end{aligned}
$$

The integral of concentration over time is converted to milligrams of the specific gas produced by the following equation:

Gas Produced (mg)

$$
=\frac{\text { Integral }\left(\frac{\mu \mathrm{L}}{\mathrm{L}} \cdot \mathrm{s}\right) \times \text { Flow rate }\left(\frac{\mathrm{mL}}{\mathrm{s}}\right) \times \mathrm{MW}\left(\frac{\mathrm{mg}}{\mathrm{mmol}}\right)}{10^{6}\left(\frac{\mathrm{mL}}{\mathrm{L}}\right) \times 24.45\left(\frac{\mathrm{mL}}{\mathrm{mmol}}\right)}
$$

The flow rate is $1035 \mathrm{~mL} / \mathrm{min}(1000 \mathrm{~mL} / \mathrm{min}$ from the carrier gas helium and $35 \mathrm{~mL} / \mathrm{min}$ from the smoke).

The cigarette was lit by a Borgwaldt Technik electric cigarette lighter (Borgwaldt Technik GmbH, Hamburg, Germany). Once the cigarette was lit, the mainstream smoke passed through a Cambridge filter pad first. The aerosol and some of the heavier, condensable products were trapped by the Cambridge filter pad. The other gases in the mainstream smoke, including CO, NO and lighter organic compounds, passed through the Cambridge filter pad and entered the multi-gas analyzer.

\section{Materials}

The NANOCAT® $\mathrm{Fe}_{2} \mathrm{O}_{3}$ was purchased from MACH I, Inc. The average particle size is $3 \mathrm{~nm}$ and the BET surface area is $250 \mathrm{~m}^{2} / \mathrm{g}$, according to the manufacturer. The sample was used without further treatment. Another nanoparticle, the $\mathrm{Fe}_{3} \mathrm{O}_{4}$ nanoparticle, which has an average particle size of $60 \mathrm{~nm}$, was also acquired from the same manufacturer. It was also used without any further treatment. The gases used in the flow tube reactor tests were $4 \% \mathrm{CO}, 21 \% \mathrm{O}_{2}$, mixture of $3.44 \% \mathrm{CO}$ with $20.6 \%$ of $\mathrm{O}_{2}$, and $995 \mu \mathrm{L} / \mathrm{L}$ of NO, all balanced with Helium (He). They were purchased from BOC Gases (BOC Gases, Murray Hill, NJ) with certified analysis. The concentrations of CO and $\mathrm{NO}$ were selected roughly based on the concentrations of $\mathrm{CO}$ and $\mathrm{NO}$ in the filter end of a cigarette during puffing.

\section{RESULTS AND DISCUSSION}

\section{Thermodynamic considerations}

The oxidation of $\mathrm{CO}$ by $\mathrm{O}_{2}$ is highly exothermic with the enthalpy of the reaction $(\Delta H)$ more than $280 \mathrm{~kJ} / \mathrm{mol}$ in a wide temperature range, as shown in Figure 3 , where the data were taken from reference (5). The negative Gibbs free energy $(\Delta G)$ values in the entire temperature range in Figure 3 also indicate that the reaction is a spontaneous reaction if the kinetic reaction barrier can be lowered by the proper catalysts. By incorporating a catalyst into a cigarette to remove $\mathrm{CO}$, the heat generated by the $\mathrm{CO}$ oxidation has to be considered. The $\mathrm{CO}$ catalyst can be put in the cigarette filler rod or cigarette filter, with respective advantages and disadvantages. In the cigarette filler rod there is high temperature available in the combustion zone and pyrolysis zone. Therefore, it does not require the $\mathrm{CO}$ catalyst to be activated at ambient temperature. However, in the high temperature zones, $\mathrm{O}_{2}$ is significantly depleted $(6,7,8)$. In addition to that, in a burning cigarette with the $\mathrm{CO}$ catalyst evenly distributed along the filler rod, only a fraction of the $\mathrm{CO}$ catalyst is activated at a time, depending on the length of the high temperature zone. On the other hand, there is not a high temperature zone available in the cigarette filter, at least not for the first few puffs, thus a CO catalyst that can be activated at ambient temperature is required. This requirement would significantly limit the choices of available catalysts. Putting the CO catalyst in the filter does have the advantage of making more efficient utilization of the catalyst since all of the catalyst, not just a fraction of it as is the case when the catalyst is put in the filler rod, will be activated at one time. However, a simple calculation in the next paragraph will show that the buildup of heat by the catalytic oxidation of $\mathrm{CO}$ by $\mathrm{O}_{2}$ will be an almost insurmountable problem.

Suppose CO is converted $100 \%$ in the filter, the heat $(h)$ generated by the oxidation of the $4 \%$ of $\mathrm{CO}$ contained in one FTC puff $(35 \mathrm{~mL})$ at the room temperature is

$$
h=n \cdot \Delta H=\frac{35(\mathrm{~mL}) \times 0.04}{24.45\left(\frac{\mathrm{mL}}{\mathrm{mmol}}\right)} \cdot 283\left(\frac{\mathrm{J}}{\mathrm{mmol}}\right)
$$

$=16.2(\mathrm{~J})$ 


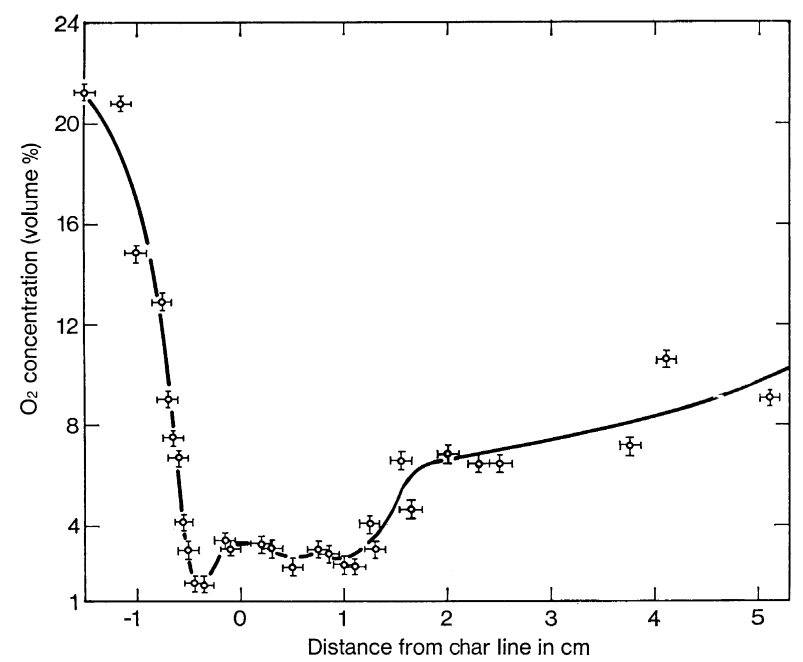

Figure 4. The one-dimensional oxygen concentration profile along the cigarette rod during a puff (graph reproduced from reference (6), Beitr. Tabakforsch. 8 (1975) 219-224, Figure 2, p. 220)

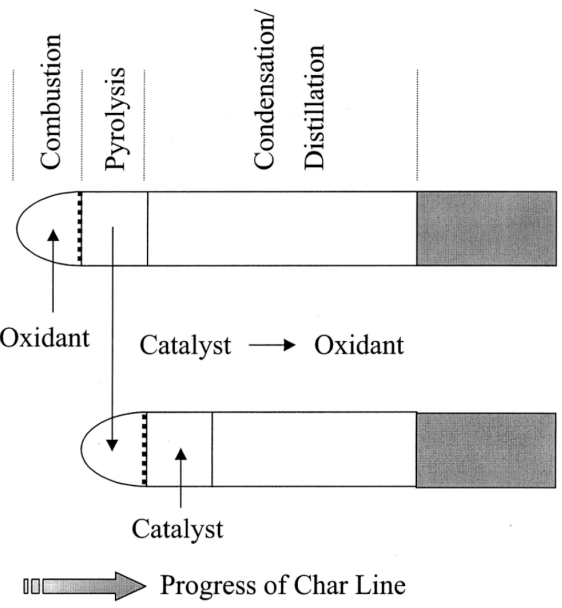

Figure 5. The schematic diagram of the proposed working mechanism of the single catalyst/oxidant applied to the cigarette filler

where $n$ is the number of moles of $\mathrm{CO}$ contained in $35 \mathrm{~mL}$ FTC puff, $\Delta H$ is the heat of reaction for $\mathrm{CO}$ oxidation, which is $283 \mathrm{~kJ} / \mathrm{mol}$ at $25^{\circ} \mathrm{C}(5)$. The enthalpy generated in the $\mathrm{CO}$ oxidation will heat up both the filter and $35 \mathrm{~mL}$ of the air in this one puff. The cigarette's filter is cellulose acetate with a heat capacity of $1.5 \mathrm{~J} / \mathrm{g} \cdot{ }^{\circ} \mathrm{C}$ and a typical filter weighs 110 $\mathrm{mg}$. The air's heat capacity is $1.03 \mathrm{~J} / \mathrm{g} \cdot{ }^{\circ} \mathrm{C}(9)$ and $35 \mathrm{~mL}$ of air weighs $42 \mathrm{mg}$. Assuming both air and the filter are heated up to the same temperature, the net temperature increase $\Delta T$ will be

$$
\begin{aligned}
\Delta T & =\frac{16.2(\mathrm{~J})}{0.11(\mathrm{~g}) \cdot 1.5\left(\frac{\mathrm{J}}{\mathrm{g} \cdot{ }^{\circ} \mathrm{C}}\right)+0.042(\mathrm{~g}) \cdot 1.03\left(\frac{\mathrm{J}}{\mathrm{g} \cdot{ }^{\circ} \mathrm{C}}\right)} \\
& =78^{\circ} \mathrm{C} .
\end{aligned}
$$

Therefore, the catalytic oxidation of $\mathrm{CO}$ could potentially increase the temperature of the filter as much as $78{ }^{\circ} \mathrm{C}$ in just one puff. Therefore, during the smoking of a cigarette with an average of 8 to 10 puffs, there would be a significant increase of the filter's temperature.
The direct oxidation of $\mathrm{CO}$ with other oxidative reagents, such as metal oxides, is much less exothermic. For example, the enthalpy $(\Delta H)$ of direct oxidation of $\mathrm{CO}$ by $\mathrm{Fe}_{2} \mathrm{O}_{3}$ is $44 \mathrm{~kJ} / \mathrm{mol}$ (5). However, direct oxidation usually can not proceed until the temperature reaches a few hundred degrees Celsius. Therefore, if the oxidative reagents are to be positioned in the filter, they have to be heated by some means and that again would result in the temperature of the filter being too high.

This thermodynamic analysis points out that the cigarette filter might not be a suitable place to conduct either catalytic oxidation or direct oxidation of $\mathrm{CO}$ in the mainstream smoke. The next section will show that cut filler in the cigarette column might be a better place to accomplish $\mathrm{CO}$ removal.

NANOCAT® $\mathrm{Fe}_{2} \mathrm{O}_{3}$ as a single catalyst/oxidant in cigarette filler for simultaneous $\mathrm{CO}$ and $\mathrm{NO}$ removal: a novel working mechanism

A burning cigarette can roughly be divided into three zones along the axial direction with different temperature ranges: that is, the combustion zone $\left(950-700{ }^{\circ} \mathrm{C}\right)$, the pyrolysis/distillation zone $\left(600-200^{\circ} \mathrm{C}\right)$, and the condensation/filtration zone (200 ${ }^{\circ} \mathrm{C}$ to ambient) (10). A one dimensional oxygen concentration profile along the cigarette rod during a puff, measured by LANZILLOTTI and WAYTE (6), is shown in Figure 4. It can be seen from Figure 4 that in the combustion zone, oxygen is severely depleted. BAKER also reported that the oxygen concentration in the combustion zone is less than $0.1 \%$ (8). However, a $\mathrm{CO}$ oxidant can oxidize $\mathrm{CO}$ directly in the absence of oxygen in the right temperature range. In the pyrolysis zone, the oxygen concentration is recovered somewhat to about $3 \%$ due to dilution from the air flow. This $3 \%$ of oxygen is a valuable source to be utilized to oxidize $\mathrm{CO}$ to $\mathrm{CO}_{2}$ through catalytic reaction. The temperature of $600-200{ }^{\circ} \mathrm{C}$ in the pyrolysis/distillation zone is high enough for a suitable $\mathrm{CO}$ catalyst to be activated. The oxygen concentration continues to recover in the condensation/filtration zone but the temperature in this zone quickly approaches ambient and probably is not high enough to activate any commercially available, non-precious metal based $\mathrm{CO}$ catalyst.

As will be shown by the following discussion, the unique temperature and oxygen profiles in a burning cigarette indicate that it is not enough to just put a good CO catalyst in the filler because of oxygen deficiency in the combustion zone. It is better if the $\mathrm{CO}$ catalyst is also a $\mathrm{CO}$ oxidant such as some metal oxides. For a CO catalyst/oxidant to be effective, it also needs to be in a highly dispersed form with high surface area so that a small amount of it can be distributed evenly over the entire cut filler in the cigarette. NANOCAT ${ }^{\circledR}$ $\mathrm{Fe}_{2} \mathrm{O}_{3}$, with its multiple functions for $\mathrm{CO}$ and $\mathrm{NO}$ removal (will be described in details later) and its small particle size and high surface area, fits this unique application quite well. Based on the unique temperature and oxygen profiles in a burning cigarette described above, we propose a novel working mechanism to remove $\mathrm{CO}$ in the mainstream smoke as illustrated in Figure 5. A single CO catalyst/oxidant material is distributed evenly in the cigarette's filler. During a cigarette's smoking process, as the char line moves towards the filter end, this single catalyst/oxidant 


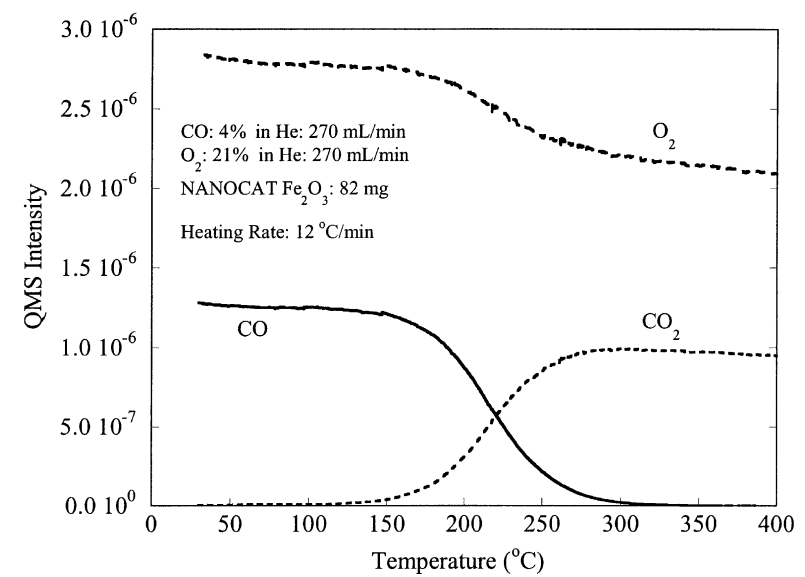

Figure 6. $\mathrm{NANOCAT}{ }^{\circledR} \mathrm{Fe}_{2} \mathrm{O}_{3}$ as a $\mathrm{CO}$ catalyst

will go through the pyrolysis zone first, then go through the combustion zone, as shown in Figure 5. When it goes through the pyrolysis zone, it will behave as a $\mathrm{CO}$ catalyst, catalyzing the $\mathrm{CO}$ to $\mathrm{CO}_{2}$ oxidation. After it is used as a $\mathrm{CO}$ catalyst, it will be used AGAIN as a $\mathrm{CO}$ oxidant when it goes through the combustion zone. Thus, the same material will be used twice, first as a catalyst, then as an oxidant, during the cigarette's burning process. Potentially, a significant CO removal could be achieved with a minimal amount of the single catalyst/oxidant added in the filler. In a standard smoking condition, the residence time of the gas flow in the combustion and pyrolysis zone is very short. For a $35 \mathrm{~mL} / 2 \mathrm{~s}$ standard puff, the linear velocity of the gas flow in the cigarette is $35.7 \mathrm{~cm} / \mathrm{s}$ (calculated with the cigarette's inner diameter of $0.79 \mathrm{~cm}$ ). Suppose the length of the combustion zone and the pyrolysis zone is about 0.7 $\mathrm{cm}$ each during the smoking (7), then the residence time of the gases in each zone is only $20 \mathrm{~ms}$. Therefore, to effectively remove $\mathrm{CO}$ and $\mathrm{NO}$ from the mainstream smoke by applying catalyst/oxidant in the cut filler, the potential catalyst/oxidant should have a very small particle size and a large surface area. The very small particle size will ensure that a small quantity of the catalyst/oxidant can be well dispersed on the entire cut filler in the cigarette. The large surface area will ensure that there is sufficient contact between reactant gases and the catalyst/oxidant.

We have identified NANOCAT ${ }^{\circledR} \mathrm{Fe}_{2} \mathrm{O}_{3}$ as a very promising candidate for this application (11). Iron oxide powder has been tried before to remove $\mathrm{CO}$ from cigarette smoke without much success (12). However, it will be shown in the following sections that NANOCAT® $\mathrm{Fe}_{2} \mathrm{O}_{3}$ is much more effective as a $\mathrm{CO}$ catalyst due to its very small particle size of $3 \mathrm{~nm}$ and large surface area of $250 \mathrm{~m}^{2} / \mathrm{g}$. It also has a unique phase composition that makes its activation temperature $150{ }^{\circ} \mathrm{C}$ lower than the activation temperatures of other micron-sized iron oxides. Therefore, a good dispersion of catalyst/oxidant with a sufficiently high surface area could be achieved by applying NANOCAT® $\mathrm{Fe}_{2} \mathrm{O}_{3}$ in the cigarette cut filler.

In addition to being effective as a $\mathrm{CO}$ catalyst and a $\mathrm{CO}$ oxidant, the reduced forms of NANOCAT® $\mathrm{Fe}_{2} \mathrm{O}_{3}$ (i.e. $\mathrm{Fe}_{3} \mathrm{O}_{4}$, $\mathrm{FeO}$, and $\mathrm{Fe}$ ) could also be used to reduce $\mathrm{NO}$ in the mainstream smoke to $\mathrm{N}_{2}$. $\mathrm{Fe}_{3} \mathrm{O}_{4}$ is known as the active component in iron oxide based catalyst for $\mathrm{CO}+\mathrm{NO}$ reaction under oxy- gen deficient conditions (13). The reaction produces $\mathrm{N}_{2}$ and $\mathrm{CO}_{2}$. The freshly formed $\mathrm{Fe}$ is a catalyst for the disproportionation reaction of $\mathrm{CO}$ that produces carbon and $\mathrm{CO}_{2}$ and thus further removes $\mathrm{CO}$ (11). Therefore, the multiple functions of one single material such as NANOCAT® $\mathrm{Fe}_{2} \mathrm{O}_{3}$, could be used in the cigarette filler for the simultaneous $\mathrm{CO}$ and $\mathrm{NO}$ removal as summarized below:

a) In the pyrolysis zone, $\mathrm{Fe}_{2} \mathrm{O}_{3}$ is used as a catalyst for the $\mathrm{CO}$ oxidation by $\mathrm{O}_{2}$ :

$$
2 \mathrm{CO}+\mathrm{O}_{2}=2 \mathrm{CO}_{2}
$$

b) As the cigarette burning proceeds, the pyrolysis zone becomes the combustion zone. The $\mathrm{Fe}_{2} \mathrm{O}_{3}$ used in the pyrolysis zone as the catalyst for $\mathrm{CO}$ oxidation is used again here as an oxidant for direct $\mathrm{CO}$ oxidation:

$$
\begin{gathered}
3 \mathrm{Fe}_{2} \mathrm{O}_{3}+\mathrm{CO}=2 \mathrm{Fe}_{3} \mathrm{O}_{4}+\mathrm{CO}_{2} \\
\mathrm{Fe}_{3} \mathrm{O}_{4}+\mathrm{CO}=3 \mathrm{FeO}+\mathrm{CO}_{2} \\
\mathrm{FeO}+\mathrm{CO}=\mathrm{Fe}+\mathrm{CO}_{2}
\end{gathered}
$$

c) In the combustion zone, where most of $\mathrm{NO}$ is produced, the freshly formed $\mathrm{Fe}_{3} \mathrm{O}_{4}$ catalyzes the $\mathrm{CO}+\mathrm{NO}$ reaction:

$$
2 \mathrm{CO}+2 \mathrm{NO}=2 \mathrm{CO}_{2}+\mathrm{N}_{2}
$$

d) Also in the combustion zone, the newly formed Fe could catalyze the disproportionation of $\mathrm{CO}$ and further removes CO:

$$
\mathrm{CO}+\mathrm{CO}=\mathrm{C}+\mathrm{CO}_{2}
$$

\section{Characterization of $\mathrm{NANOCAT \circledR} \mathrm{Fe}_{2} \mathrm{O}_{3}$ as $\mathrm{CO}$ and $\mathrm{NO}$ catalyst by flow tube method}

In this section NANOCAT® $\mathrm{Fe}_{2} \mathrm{O}_{3}$ is characterized briefly as a $\mathrm{CO}$ catalyst, a $\mathrm{CO}$ oxidant and in its reduced forms as a catalyst for the $\mathrm{CO}+\mathrm{NO}$ reaction. More detailed information about the reaction kinetics and mechanism of nanoparticle iron oxide as a $\mathrm{CO}$ catalyst and its stepwise reduction by $\mathrm{CO}$ can be found in reference (11).

a) NANOCAT® $\mathrm{Fe}_{2} \mathrm{O}_{3}$ as $\mathrm{CO}$ catalyst and oxidant: Here only the characteristics of NANOCAT ${ }^{\circledR} \mathrm{Fe}_{2} \mathrm{O}_{3}$ as a $\mathrm{CO}$ catalyst and as a $\mathrm{CO}$ oxidant are shown. In Figure 6, NANOCAT ${ }^{\circledR} \mathrm{Fe}_{2} \mathrm{O}_{3}$ is characterized as a $\mathrm{CO}$ catalyst. The catalyst was activated at $150{ }^{\circ} \mathrm{C}$ and quickly reached full capacity. The activation temperature of $150{ }^{\circ} \mathrm{C}$ makes it very suitable for application in the pyrolysis zone of a burning cigarette that has a temperature range of 600 to $200{ }^{\circ} \mathrm{C}$.

After the NANOCAT® $\mathrm{Fe}_{2} \mathrm{O}_{3}$ sample in Figure 6 was tested as a CO catalyst, the sample was cooled down to the room temperature under the protective environment of helium gas. Then the same sample was tested again as a $\mathrm{CO}$ oxidant and the result is shown in Figure 7. In this test, only $4 \% \mathrm{CO}$ in helium was passed through the sample and the temperature was increased as quickly as possible to $460{ }^{\circ} \mathrm{C}$, which was chosen because it is high enough for reaction [6]-[8] to occur. The decrease of $\mathrm{CO}$ and the increase of $\mathrm{CO}_{2}$ in the effluent flow were almost a mirror image of each other. In this direct oxidation, $\mathrm{CO}$ was oxidized by NANOCAT® $\mathrm{Fe}_{2} \mathrm{O}_{3}$ to $\mathrm{CO}_{2}$ and the NANOCAT ${ }^{\circledR} \mathrm{Fe}_{2} \mathrm{O}_{3}$ was reduced to different reduced forms $\left(\mathrm{Fe}_{3} \mathrm{O}_{4}, \mathrm{Fe}\right)$. In the combustion zone of a burning cigarette, the temperature is high enough $\left(900\right.$ to $700{ }^{\circ} \mathrm{C}$ ) for NANOCAT® $\mathrm{Fe}_{2} \mathrm{O}_{3}$ to be used again as a $\mathrm{CO}$ oxidant to reduce $\mathrm{CO}$ in the smoke. Therefore, in the burning process, the NANOCAT® $\mathrm{Fe}_{2} \mathrm{O}_{3}$ 


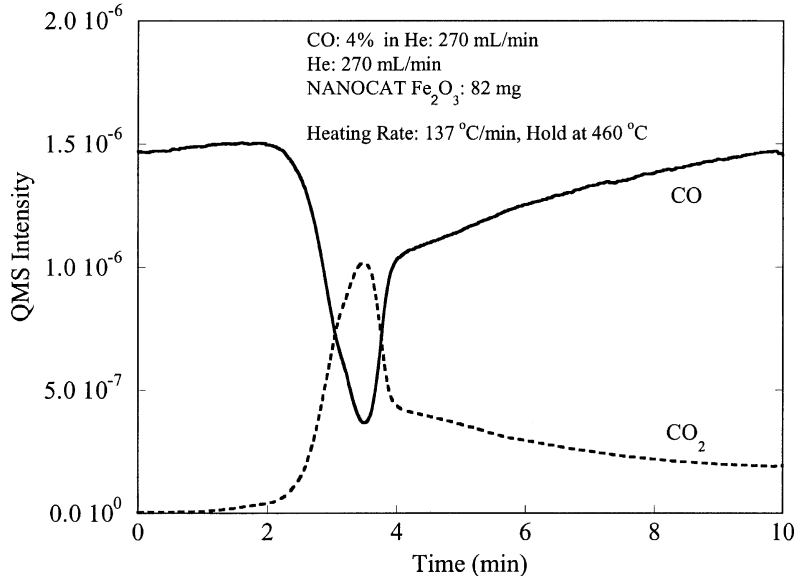

Figure 7. NANOCAT® $\mathrm{Fe}_{2} \mathrm{O}_{3}$ as a $\mathrm{CO}$ oxidant

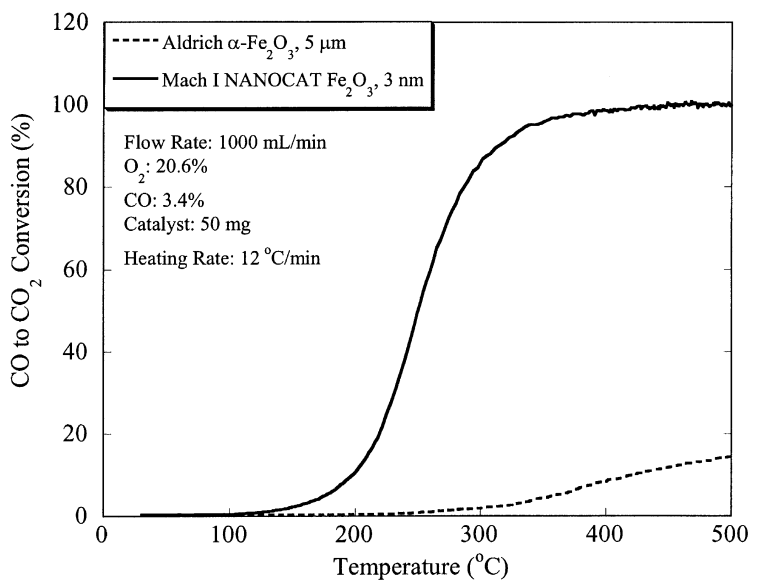

Figure 8. The comparison of the catalytic activity of NANOCAT® $\mathrm{Fe}_{2} \mathrm{O}_{3}$ and Aldrich $\alpha-\mathrm{Fe}_{2} \mathrm{O}_{3}$

applied in the filler can be used two times, first as a $\mathrm{CO}$ catalyst in the pyrolysis zone, then as a $\mathrm{CO}$ oxidant in the combustion zone.

The nano-sized NANOCAT® $\mathrm{Fe}_{2} \mathrm{O}_{3}$ is much more effective as a $\mathrm{CO}$ catalyst than other micron-sized iron oxide powders, as shown in Figure 8. In this experiment, the same amount of NANOCAT® $\mathrm{Fe}_{2} \mathrm{O}_{3}$ and Aldrich's $\alpha-\mathrm{Fe}_{2} \mathrm{O}_{3}$ were tested respectively in the flow tube reactor, under identical conditions, for effectiveness as a CO catalyst. There are two significant differences in catalytic performance between these two materials. First, the activation temperature of nanoparticle iron oxide is at least one hundred and fifty degrees lower than that of $\alpha-\mathrm{Fe}_{2} \mathrm{O}_{3}(150$ ${ }^{\circ} \mathrm{C}$ vs. $300{ }^{\circ} \mathrm{C}$ ). Second, the percentage of $\mathrm{CO}$ conversion is much higher with nanoparticle iron oxide than with $\alpha-\mathrm{Fe}_{2} \mathrm{O}_{3}$ $\left(98 \%\right.$ vs. $10 \%$ at $\left.400{ }^{\circ} \mathrm{C}\right)$. The very small particle size (3 $\mathrm{nm})$ and the larger BET surface area of nanoparticle iron oxide $\left(250 \mathrm{~m}^{2} / \mathrm{g}\right.$ vs. $3.2 \mathrm{~m}^{2} / \mathrm{g}$ for $\left.\alpha-\mathrm{Fe}_{2} \mathrm{O}_{3}\right)$ very likely contribute to the higher $\mathrm{CO}$ conversion rate. The low activation temperature of nanoparticle iron oxide probably comes from the $\mathrm{FeOOH}$ component existing in this material, as discussed in reference (11). The detailed kinetic and structural studies of the $\mathrm{Fe}_{2} \mathrm{O}_{3}$ can be seen there.

b) The reduced form of $\mathrm{NANOCT}{ }^{\circledR} \mathrm{Fe}_{2} \mathrm{O}_{3}$ as a catalyst of $2 \mathrm{CO}+2 \mathrm{NO}=2 \mathrm{CO}_{2}+\mathrm{N}_{2}$ reaction: As mentioned in the pre-

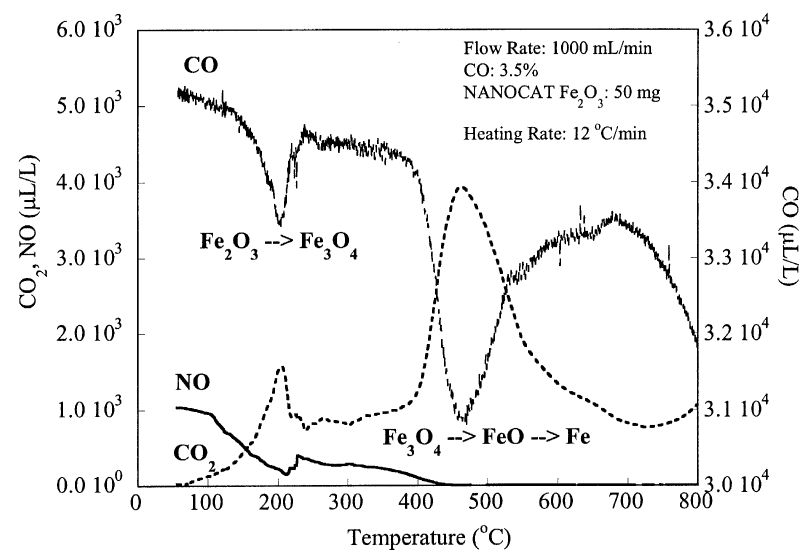

Figure 9. $\mathrm{CO}+\mathrm{NO}$ reaction catalyzed by $\mathrm{Fe}_{3} \mathrm{O}_{4}$ generated in situ from NANOCAT® $\mathrm{Fe}_{2} \mathrm{O}_{3}$

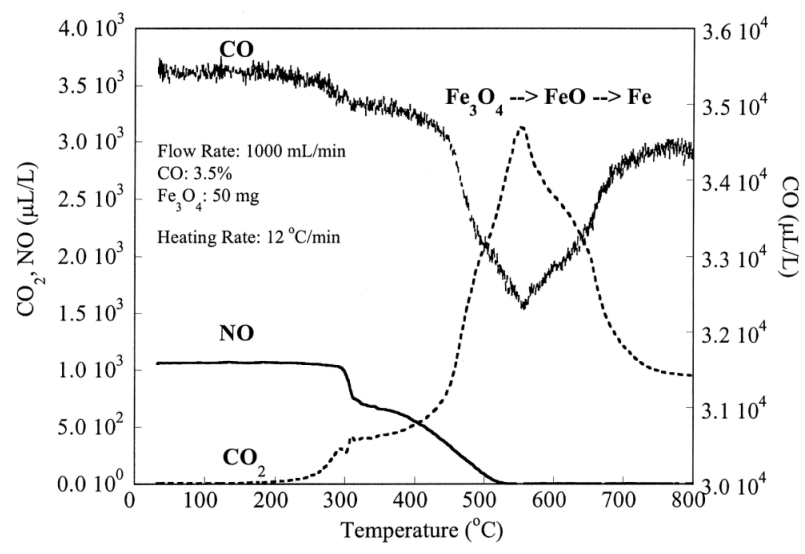

Figure 10. $\mathrm{CO}+\mathrm{NO}$ reaction catalyzed by the pre-fabricated $\mathrm{Fe}_{3} \mathrm{O}_{4}$

vious section, $\mathrm{Fe}_{3} \mathrm{O}_{4}$ is known to be the active catalytic component for the $\mathrm{CO}+\mathrm{NO}$ reaction (13). In Figure 9, the inlet gas consists of $\mathrm{CO}, \mathrm{NO}$ but not $\mathrm{O}_{2}$. As the temperature increases, first $\mathrm{CO}$ stepwise reduces NANOCAT® $\mathrm{Fe}_{2} \mathrm{O}_{3}$ to $\mathrm{Fe}_{3} \mathrm{O}_{4}$, then to $\mathrm{FeO}$ and $\mathrm{Fe}$. As soon as $\mathrm{Fe}_{3} \mathrm{O}_{4}$ is formed, as indicated by the decrease of $\mathrm{CO}$ and the increase of $\mathrm{CO}_{2}, \mathrm{NO}$ starts to decrease, at the temperature of only $110{ }^{\circ} \mathrm{C}$. The experiment indicates that the in situ generated $\mathrm{Fe}_{3} \mathrm{O}_{4}$ is a very active catalyst for $\mathrm{CO}+\mathrm{NO}$ reaction. This conclusion is further confirmed by another experiment, in which the commercial $\mathrm{Fe}_{3} \mathrm{O}_{4}$ nanoparticles were tested under identical conditions and the result is shown in Figure 10. The $\mathrm{CO}$ peak corresponding to the reduction of $\mathrm{Fe}_{2} \mathrm{O}_{3}$ to $\mathrm{Fe}_{3} \mathrm{O}_{4}$ disappears since the starting material is already in the $\mathrm{Fe}_{3} \mathrm{O}_{4}$ form. The decrease of NO is not observed until $300{ }^{\circ} \mathrm{C}$. In the later section, the test result in a cigarette also reveals that the in situ generated $\mathrm{Fe}_{3} \mathrm{O}_{4}$ is more active in removing $\mathrm{NO}$ than the pre-fabricated one.

\section{The effect of smoke condensate on catalyst}

Applying catalysts in a cigarette is a unique challenge since many other smoke constituents can potentially deactivate the catalyst or participate in a competitive reaction. During the smoking process, the smoke condensate will condense indiscriminately in the cool zone on both the cut filler and 


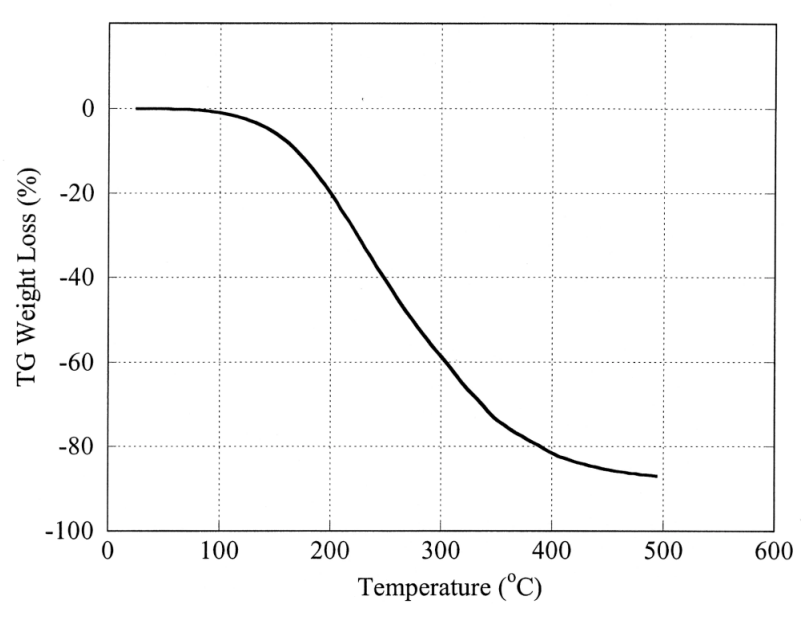

Figure 11. TG trace of the bright tobacco condensate; heating rate: $20^{\circ} \mathrm{C} / \mathrm{min}$.

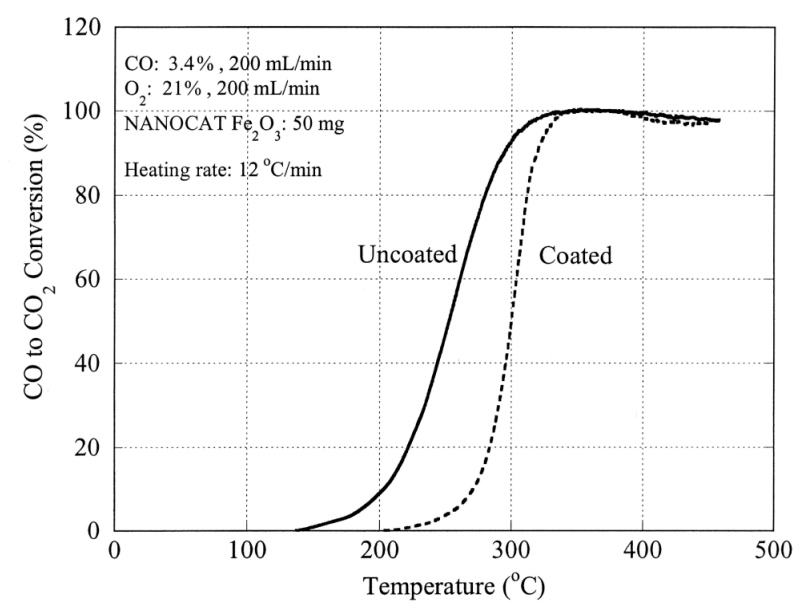

Figure 12. Comparison of the catalytic performance of NANOCAT ${ }^{\circledR} \mathrm{Fe}_{2} \mathrm{O}_{3}$ with and without the smoke condensate coating

catalyst. Therefore, the influence of the smoke condensate on the catalyst becomes very important. It could even be the controlling factor of the catalytic performance. It is obvious that once the smoke condensate is condensed on the catalyst, the smoke condensate has to be vaporized or decomposed before the catalyst can regain any catalytic activity. Thus, the temperature at which most of the smoke condensate either vaporizes or decomposes will become the actual activation temperature, i.e. the temperature for the catalyst to begin functioning in a cigarette. This temperature could be significantly higher than the intrinsic activation temperature for the same catalyst in other well-controlled chemical environments such as those described in the flow tube experiment earlier.

The majority of the smoke condensate vaporizes when the temperature reaches $300-400{ }^{\circ} \mathrm{C}$, as shown in Figure 11. In this Thermal Gravimetric (TG) experiment, $10 \mathrm{mg}$ of condensate from the pyrolysis of bright tobacco was heated in $150 \mathrm{~mL} / \mathrm{min}$ of helium flow at the heating rate of $20{ }^{\circ} \mathrm{C} / \mathrm{min}$. It is clear that the bright condensate starts to vaporize at $100{ }^{\circ} \mathrm{C}$. At $250{ }^{\circ} \mathrm{C}$, about $40 \%$ vaporizes and at $350{ }^{\circ} \mathrm{C}$, about $70 \%$ vaporizes.
When the smoke condensate coated on the catalyst starts to vaporize or decompose, some portion of the catalyst surface could become exposed and becomes catalytically active again assuming that the active catalytic sites are not destroyed during the condensation and vaporization of the smoke condensate. The effect of smoke condensate on the catalyst can be tested outside of a cigarette by testing the smoke condensate-coated catalyst. The coating of the smoke condensate is briefly described here: The smoke condensate was generated from the pyrolysis of $1 \mathrm{~g}$ of bright tobacco in a flow tube at $300{ }^{\circ} \mathrm{C}$ in helium flow. Fifty milligram of NANOCAT $® \mathrm{Fe}_{2} \mathrm{O}_{3}$ was put in the down stream of the flow tube in the cool zone. The generated condensate in the hot zone was carried over by helium flow to the cool zone and condensed on the nanoparticle iron oxide sample. The NANOCAT $\mathrm{Fe}_{2} \mathrm{O}_{3}$ sample was then taken out of the flow tube and tested as a $\mathrm{CO}$ catalyst. Figure 12 compares the performance of the catalyst coated with smoke condensate and the fresh sample. It is obvious that the coated sample loses catalytic activity at the low temperature. However, as the temperature increases, the coated catalyst starts to regain some catalytic activity at about $250{ }^{\circ} \mathrm{C}$. When the temperature reaches $350{ }^{\circ} \mathrm{C}$, the coated catalyst regains $100 \%$ of its catalytic activity and in fact, it performs identically to an un-coated catalyst. This observation is in agreement with the fact that at $350{ }^{\circ} \mathrm{C}$ the majority of the smoke condensate has devolatilized. Two useful conclusions can be drawn from this set of experiments. First, the catalytically active sites on NANOCAT ${ }^{\circledR}$ $\mathrm{Fe}_{2} \mathrm{O}_{3}$ are not destroyed by the condensation and vaporization of the smoke condensate. Second, the vaporization process of the smoke, to certain extent, dictates the actual activation temperature of the catalyst, regardless of the intrinsic activation temperature of the catalyst.

\section{Test results in a cigarette}

The multiple functions for the CO removal by NANOCAT ${ }^{\circledR}$ $\mathrm{Fe}_{2} \mathrm{O}_{3}$ and the test results from the smoke condensate coating experiment indicate that this material should be able to remove $\mathrm{CO}$ from the mainstream smoke in the cigarette to a certain extent. The test results in the cigarette confirm that this is the case. In the cigarette test, mixed blends commercial cut filler was used to make both control and experimental cigarettes. The amount of $0.74 \mathrm{~g}$ of cut filler was used for each control cigarette. For the experimental cigarette, $3 \mathrm{wt} \%$ of NANOCAT® $\mathrm{Fe}_{2} \mathrm{O}_{3}$ was applied to the same amount of cut filler. Both control and experimental cut fillers were then made into cigarettes by a Supermatic $₫$ cigarette maker. Five control cigarettes and five experimental cigarettes were smoked by the puff-by-puff smoking machine described in the experimental section and $\mathrm{CO}, \mathrm{NO}$ were measured.

Compared to the control cigarette, the $\mathrm{CO}$ in the experimental cigarette is reduced from $14.8( \pm 0.8) \mathrm{mg}$ to 9.3 $( \pm 0.6) \mathrm{mg}$, a $37 \%$ reduction. The puff count is also reduced slightly from $8.2( \pm 0.1)$ to $7.6( \pm 0.3)$. For the NO test, an additional set of experimental cigarettes was made. An amount of $1.5 \%$ of NANOCAT® $\mathrm{Fe}_{2} \mathrm{O}_{3}$ plus $1.5 \%$ of $\mathrm{Fe}_{3} \mathrm{O}_{4}$ were applied to the cut filler of this set. The purpose is to correlate the test result from the flow tube method to the actual catalytic performance of these two materials in a cigarette. The results from the flow tube test indicate that 
NANOCAT® $\mathrm{Fe}_{2} \mathrm{O}_{3}$ is more active in NO removal than $\mathrm{Fe}_{3} \mathrm{O}_{4}$ because it could generate fresh $\mathrm{Fe}_{3} \mathrm{O}_{4}$ in situ. The test result in a cigarette shows that with $3 \%$ of $\mathrm{Fe}_{2} \mathrm{O}_{3}$ in the cut filler, NO is reduced from $328( \pm 13) \mu \mathrm{g}$ to $179( \pm 19) \mu \mathrm{g}$, a $45 \%$ reduction. However, with $1.5 \%$ of $\mathrm{Fe}_{2} \mathrm{O}_{3}$ plus $1.5 \%$ of $\mathrm{Fe}_{3} \mathrm{O}_{4}$, NO is only reduced to $234( \pm 35) \mu \mathrm{g}$, a $29 \%$ reduction. The result in the cigarette test is in good agreement with the flow tube test. It indicates that in situ produced $\mathrm{Fe}_{3} \mathrm{O}_{4}$ is a more active catalyst for the $\mathrm{CO}+\mathrm{NO}$ reaction in a cigarette.

These test results clearly show the promise of NANOCAT® $\mathrm{Fe}_{2} \mathrm{O}_{3}$ as a single catalyst/oxidant that can simultaneously remove $\mathrm{CO}$ and $\mathrm{NO}$ in the mainstream smoke in a burning cigarette. NANOCAT® $\mathrm{Fe}_{2} \mathrm{O}_{3}$ is a non-precious metal based catalyst that it is especially suitable in a nonrecyclable application such as a cigarette.

\section{CONCLUSIONS}

NANOCAT ${ }^{\circledR} \mathrm{Fe}_{2} \mathrm{O}_{3}$ is identified as a promising cut filler additive to reduce $\mathrm{CO}$ and $\mathrm{NO}$ in mainstream cigarette smoke. It can be used as a CO catalyst in the presence of $\mathrm{O}_{2}$ and used again as a $\mathrm{CO}$ oxidant in the absence of $\mathrm{O}_{2}$. The activation temperature of NANOCAT® $\mathrm{Fe}_{2} \mathrm{O}_{3}$ as a catalyst and as an oxidant match very well with the temperature and oxygen profiles of the pyrolysis zone and the combustion zone in a burning cigarette. In addition, the reduced form of NANOCAT ${ }^{\circledR} \mathrm{Fe}_{2} \mathrm{O}_{3}$ removes $\mathrm{NO}$ by catalyzing the $\mathrm{CO}+$ $\mathrm{NO}$ reaction in the combustion zone of the cigarette. The influence of the smoke condensate on the catalyst was evaluated. It was found that its effect on the catalytic performance of NANOCAT® $\mathrm{Fe}_{2} \mathrm{O}_{3}$ is minimal at high temperatures. It is potentially feasible to reduce a significant amount of $\mathrm{CO}$ and $\mathrm{NO}$ in the mainstream smoke by including a small amount ( $3 \mathrm{wt} \%$ ) of NANOCAT ${ }^{\circledR} \mathrm{Fe}_{2} \mathrm{O}_{3}$ in the cigarette's filler. The test results of applying NANOCAT® $\mathrm{Fe}_{2} \mathrm{O}_{3}$ on cigarette filler to reduce $\mathrm{CO}$ and $\mathrm{NO}$ is very encouraging.

\section{ACKNOWLEDGEMENT}

The authors gracefully acknowledge the literature survey on previous research of CO reduction in cigarette smoke by Dr. Robert N. Ferguson and Dr. Peter J. Lipowicz, and the technical and editorial comments by Dr. Robert Fenner. The authors also thank Bruce E. Waymack and Dr. Oja Vahur for providing TG information of smoke condensate and Shahryar Rabiei's assistance in the catalyst coating experiments.

\section{REFERENCES}

1. Baker, R.R.: Mechanisms of smoke formation and delivery; Rec. Adv. Tob. Sci. 6 (1980) 184-224.
2. Baker, R.R.: A review of pyrolysis studies to unravel relation steps in burning tobacco; J. Anal. Appl. Pyrolysis 11 (1987) 555-573.

3. Baker, R. R.: The formation of the oxides of carbon by the pyrolysis of tobacco; Beitr. Tabaforsch. 8 (1975) 16-27.

4. Im, H., F. Rasouli, and M.R. Hajaligol: Formation of nitric oxide during tobacco oxidation; J. Agric. Food Chem. 51 (2003) 7366-7372.

5. Knacke, O., O. Kubaschewski, and K. Hesselmann: Thermochemical properties of inorganic substances I \& II; $2^{\text {nd }}$ edition, Springer-Verlag, Berlin, 1991.

6. Lanzillotti, H.V. and A.R. Wayte: One-dimensional gas concentration profiles within a burning cigarette during a puff; Beitr. Tabaforsch. 8 (1975) 219-224.

7. Baker, R.R.: Variation of the gas formation regions with a cigarette combustion coal during the smoking cycle; Beitr. Tabaforsch. Int. 11 (1981) 1-17.

8. Baker, R.R.: Combustion and thermal decomposition regions inside a burning cigarette; Combust. Flame 30 (1977) 21-32.

9. Lide, D.R.: CRC Handbook of chemistry and physics, $81^{\text {st }}$ edition, CRC Press, Boca Raton, 2000-2001, pp. 62.

10. Baker, R.R: The effect of ventilation on cigarette combustion mechanisms; Rec. Adv. Tob. Sci. 10 (1984) 88-150.

11. Li, P., D. Miser, S. Rabiei, R. Yadav, and M.R. Hajaligol: The removal of carbon monoxide by iron oxide nanoparticles; Appl. Catalysis B: Environmental 43 (2003) 151-162.

12. Andrews, M.N. and J.H. Reynolds: Tobacco additives for reduction of carbon monoxide, hydrogen cyanide and oxides of nitrogen in cigarette smoke; R.J. Reynolds Tobacco Company, August 5, 1971, Bates No. 501002248, see http://www.rjitdocs.com, accessed June 20, 2002.

13. Randall, H., R. Doepper, and A. Renken: Reduction of nitric oxide by carbon monoxide over an iron oxide catalyst under dynamic conditions; Appl. Catalysis B 17 (1998) 357-369.

\section{Address for correspondence}

Mohammad Hajaligol

Philip Morris USA Inc.

Research Center

Richmond, Virginia 23234, USA

E-mail: mohammad.r.hajaligol@pmusa.com 